\title{
SURROGATE MOTHERHOOD - THE EUROPEAN LEGAL LANDSCAPE
}

\section{Lilla GARAYOVÁ ${ }^{1}$}

Surrogate motherhood is a fascinating topic that has been part of human history since time immemorial and still provides kindling for discussion in the twenty-first century. Despite its ancient origin and current topicality, in many ways, surrogacy remains under-discussed. There is no clear consensus on how to deal with it: some important values will be jeopardized regardless of the route we take. Recent developments and research in the area of human reproductive medicine have resulted in a continuous increase in surrogacies each year, so it is paramount to consider the moral, ethical, and legal implications of the practice. This article examines the history of surrogacylaws, the enforceability of surrogacy agreements, and the current legal landscape of surrogacy in Europe.

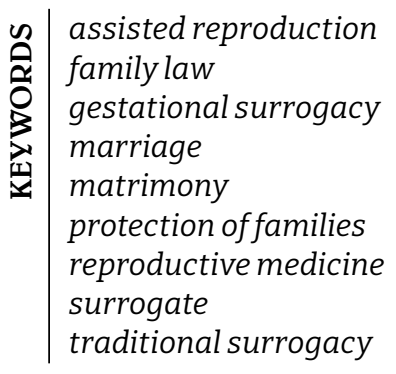

\section{Introduction}

Infertility is a serious problem that affects the social and marital lives of many couples in the twenty-first century. Until recently, couples faced with infertility issues could only decide between remaining childless or adoption. This has changed significantly with the advancement of assisted reproductive technologies. Infertile couples can now also choose between artificial insemination, in vitro fertilization, or surrogacy.

1 | Associate Professor, Department of International Law, Faculty of Law, Pan-European University, Slovakia, lilla.garayova@paneurouni.com, ORCID: 0000-0002-7999-4823. 
From a medical perspective, surrogacy is a process that begins with the conception, followed by childbearing, and childbirth by a woman who does so for the benefit of another woman who is unable to become pregnant or, for various medical indications, to bear a fetus. The culmination of this surrogacy process is the 'handing over' of the child, which, in the context of the legal options, usually involves the adoption of the child by the infertile mother (if the husband/partner of this mother is also the biological father), or adoption by the couple from the surrogate mother (if neither partner is the biological parent). ${ }^{2}$ A surrogate is a woman who becomes pregnant on behalf of someone else, usually a couple who are referred to as intended parents, or, sometimes, commissioning parents. There are several types of surrogates.

In traditional (or partial) surrogacy, the surrogate mother has a genetic link to the child through the provision of the egg (oocyte). Sperm originates from the intended father or sperm donation. In this case, the surrogate is the natural, biological, gestational, and genetic mother of the child, who relinquishes her parental rights upon childbirth. Traditional surrogacy can be accomplished via artificial insemination, which has a significantly lower cost than in vitro fertilization. However, this type of surrogacy incurs a greater risk of legal complications than gestational surrogacy.

In the case of gestational surrogacy (or full surrogacy), the surrogate mother has no genetic link to the child; the genetic material is provided by the intended parents or donors. This means that the child will have no genetic or biological link to the surrogate, and it will be genetically linked to one, both, or neither of the commissioning parents. In essence, the surrogate here only provides a 'womb to rent'. The surrogate is only the gestational mother, carrying the child to term, but she is not the genetic or biological mother. Upon childbirth, she surrenders her parental rights to her child. Gestational surrogacy is achieved through more expensive in vitro fertilization. Of the two models, this is closer to adoption itself and is much more advantageous for the intended mother. In some places, contracts for this type of surrogacy are constructed so that in the third trimester of pregnancy, an application is made for the names of the commissioning couple to be entered as parents on the child's birth certificate.

Surrogacy is an increasingly common form of reproduction for several reasons. The primary reason is the rising rate of infertility among couples. ${ }^{3}$ Meanwhile, the field of assisted reproduction has been one of the most dynamically developing branches of medicine in recent years, pushing the boundaries of biological parenthood beyond previously unprecedented horizons. Developments in the procedures of in vitro fertilization and artificial insemination have made surrogacy a viable method of reproduction for infertile couples. ${ }^{4}$

There are essentially two methods that can be used to find surrogate mothers. Either someone in the family, usually a close relative, takes on the role of the surrogate mother, which is accepted despite the genetic relationship; or in some countries, there are socalled intermediary agencies that keep lists of potential surrogate mothers and couples who wish to use this method.

Naturally, scientific opinions differ regarding the key motivating factors for this increasing number of pregnancies. Most authors differentiate between three common

2 | Erdősová, 2014, p. 1474.

3 | Dunson, Baird and Colombo, 2004, p. 51.

4 | Behm, 1999, p. 557. 
key motivators. ${ }^{5}$ The first is the gradual increase in reproductive options for couples, who are no longer forced to relinquish the idea of becoming parents because of their infertility. The second is the shift away from conventional thinking regarding issues of sexuality and family, in the broadest sense. The third and probably most important factor is the acute shortage of children available for adoption in certain countries. ${ }^{6}$ It should also be mentioned that the number of babies available for adoption must be considered in two ways-wholistically, but also practically-as statistics show that certain countries do not experience a shortage of children for adoption, but in some of these countries, many couples do not consider older children, children with disabilities, or children of a certain race to be 'adoption-worthy'- which inevitably opens up an increasingly debated topic that is usually summarized as the 'black market in white babies'. ' If it were not for this phenomenon, the need for surrogacy would probably also be much lower, especially in cases where neither of the adoptive parents of the child born to the surrogate mother is the biological parent. It can therefore be argued that one of the reasons for the growing trend in the use of surrogacy today is the 'adoption trade'. ${ }^{8}$

\section{Surrogacy: A History}

When we think about surrogacy, we often imagine a new phenomenon-a modern, alternate way of becoming a parent. In some respects, this is true: modern surrogacy as we know it today has only been around for the last forty-something years. However, the concept of surrogacy has existed since time immemorial and can be traced to biblical times. Understanding the history of traditional and modern surrogacy and using the relevant terminology is crucial for comprehending this issue and analyzing it from a legal perspective.

The first account of surrogacy can be found in the first book of the Old Testament, Genesis, in the story of Abraham. Abraham was married to a beautiful and sharp-witted woman, Sarah. She respected her husband above all else but could not conceive her own child. In order to secure an offspring and ensure succession, she turned to her servant, Hagar, and asked her to conceive and carry the child of Abraham with the understanding that Sarah would be considered the mother of the child, even though she was not biologically related. The child born from this union was named Ishmael. Over time, however, a considerable conflict arose between the women stemming from Sarah's jealousy and Hagar's inability to relinquish her claim to her child. These and similar emotions hinted at in this story are often highlighted as natural consequences when discussing the moral permissibility of surrogacy. The animosity between the two women in the biblical narrative culminates in Sarah's expulsion of Hagar and her son Ishmael after she gives birth to her own biological son, Isaac (Sarah is said to have been almost 90 years old at the time). Outside of the Bible, tales of women bearing children for rulers whose wives could not are common throughout history. Until the 1980s, these traditional types of surrogacies

5 | Posner, 1989, p. 21.

6 | Skidmore, Anderson and Eiswerth, 2012, p. 44.

7 | Solinger, 2000, p. 362.

8 | Erdősová, 2016, p. 50. 
were the only form of the practice. The topic itself was considered taboo in many cultures because of the stigma associated with infertility and illegitimacy.

Unofficial history indicates that the first artificial insemination was conducted in 1455 by Henry IV of Castilla (nicknamed the Impotent). He married Juana of Portugal, the sister of Alfonso V in Portugal. ${ }^{9}$ Six years after her marriage, she gave birth to Joanna. Many contemporary chroniclers assumed Henry to be infertile and some claimed that his wife underwent artificial insemination with the monarch's semen because of his complete erectile dysfunction. His rumored impotence was used by his enemies to deny the right of succession to his daughter Joanna, also called 'La Beltraneja'. ${ }^{10}$ Later, his paternity was also questioned. Modern-day scientists tried to resolve the enigma of this medieval insemination and, while most agree that the King was, in fact, impotent, the question of insemination has not yet been credibly verified.

Human reproductive research has always been fraught with scientific, ethical, and legal challenges that hinder the creation of infertility treatments. The first verified attempts at artificial insemination in humans were made in the nineteenth century and are linked to the physician J. Marion Sims, who conducted fifty-five postcoital inseminations using highly controversial methods, mostly on slaves, without their consent. ${ }^{11}$ Only one insemination resulted in pregnancy, which ended with a miscarriage. The low success rate of his attempts can be explained by the fact that he believed that ovulation occurred during menstruation. ${ }^{12}$

The first child conceived through artificial insemination was linked to the 1884 experiment of an American surgeon, William Pancoast. He performed a modified insemination procedure during which he injected the sperm of a donor into a female patient who was under anesthesia and not aware of the impregnation. Nine months later, she gave birth to a baby. While it was morally questionable, this experiment paved the way for future medical developments. Artificial insemination is now a crucial aspect of modern surrogacy.

Similar to artificial insemination, in vitro fertilization has been linked with many ethical dilemmas. Understanding the human body and medical development in the 1970s made the in vitro fertilization of human oocytes possible. This led to the birth of the first 'test-tube baby' in $1978 .{ }^{13}$

All of these developments in human reproduction research led society to revisit the dilemma of surrogacy in the 1970s. The first formal surrogacy contract was drafted by the attorney Noel Keane in 1976. ${ }^{14}$ Keane is considered to be the father of surrogacy law. The agreement in 1976 was a case of traditional surrogacy without monetary compensation. Only four years later, in 1980, Keane arranged the first commercial compensated surrogacy agreement in a traditional surrogacy case. The surrogate mother received a payment of $\$ 10,000 .{ }^{15}$ She eventually regretted the process and disclosed her experiences in a book called Birth Mother. The lawyer, Noel Keane, went on to establish the Infertility

9 | Ombelet and Robays, 2015, p. 138.

10 | Maganto Pavón, 2003, p. 3.

11 | Sartin, 2004, p. 97.

12 | Ombelet and Robays, 2015, p. 140.

13 | Steptoe and Edwards, 1978, p. 366.

14 | Patel and Jadeja, 2018, p. 11.

15 | Lasker, 2016. 
Center, which arranged hundreds of surrogacies annually and became the focus of deep scrutiny and debate in 1986 because of the Baby M case. In the years ensuing, amid courtroom battles and ethical, philosophical, religious, moral, and legislative debates, Keane remained a strong supporter of surrogacy.

The Baby M case was the first American court ruling on the validity of surrogacy. ${ }^{16}$ In the case, the Court was asked to determine the validity of a surrogacy contract involving traditional surrogacy. In 1984, Mary Beth Whitehead responded to an advertisement in the Ashbury Park Press that had been placed by the Infertility Center established by Noel Keane. The Center was looking for fertile women willing to become surrogate mothers to help infertile couples that wanted to have children. William and Elizabeth Stern sought a surrogate mother for their child. Elizabeth was not infertile, but she had serious health issues, including multiple sclerosis. They were concerned about the health implications of pregnancy on Elizabeth and their future child, and therefore decided to find a surrogate mother. The parties to the contract were William and Mary Beth, with the understanding that Mary Beth would be inseminated with William's sperm, carry the pregnancy to term, hand over the baby, and forgo her parental rights in favor of Elizabeth Stern, who was to adopt the child. Mary Beth's eggs were used in the insemination, making her the biological mother of the child; thus, this was a case of traditional as opposed to gestational surrogacy. The monetary compensation for the surrogacy procedure was $\$ 10,000$. After the completion of the procedure, William and Elizabeth Stern were regarded as the parents of the child for all purposes. After giving birth, Mary Beth handed over the child (Baby M) to the Sterns as agreed upon, but a few days later she had a change of heart and decided to kidnap the child. The Sterns then decided to sue Mary Beth and her husband in order to be recognized as the child's legal parents. This started a lengthy custody battle that culminated in the creation of stricter surrogacy laws in several states in the United States ${ }^{17}$ and had a global impact on surrogacy laws. It was decided that William Stern, the plaintiff, had the right to procreate and the right of a biological father to his child, while Mary Beth, the defendant, had the right of a biological mother to the child. This led to the development of public policy embodied in adoption laws against buying and selling babies and making them the subjects of ordinary contracts.

The New Jersey Supreme Court held that the surrogacy contract between Mary Beth and the Sterns was illegal and, therefore, restored Mary Beth's parental rights. William Stern was granted full custody, being the biological father of Baby M, while Mary Beth was granted visitation rights. The New Jersey Supreme Court held the following:

"We invalidate the surrogacy contract because it conflicts with the law and public policy of this State. While we recognize the depth of the yearning of infertile couples to have their own children, we find the payment of money to a 'surrogate' mother illegal, perhaps criminal, and potentially degrading to women. Although in this case, we grant custody to the natural father, the evidence clearly proving such custody to be in the best interests of the infant, we void both the termination of the surrogate mother's parental rights and the adoption of the child by the wife/stepparent. We thus restore the 'surrogate' as the mother of the child."18

16 | New Jersey Supreme Court in the Matter of Baby M. - In re Baby M. 537 A.2d 1227, 109 N.J. 396 (N.J. 02/03/1988).

$17 \mid$ Allen, 1988, p. 808.

$18 \mid$ New Jersey Supreme Court in the Matter of Baby M. - In re Baby M. 537 A.2d 1227, 109 N.J. 396

(N.J. 02/03/1988). 
The Baby $\mathrm{M}$ case undeniably marked a significant turning point in the history of surrogacy. After the judgment of the New Jersey Supreme Court, many surrogacy professionals stopped the use of traditional surrogacy and moved toward the use of gestational surrogacy. Ensuring a lack of genetic ties between the surrogate mother and the child can preemptively avoid complicated legal entanglements.

Today, thirty-five years after the Baby M case, people around the world, regardless of their marital status or sexual orientation, look to surrogacy as a viable option to have a family. However, it is clear that surrogacy remains in a moral and legal grey area. Just like abortion or euthanasia, it is a moral quandary that has no universally satisfactory solution. Regardless of how it is performed, certain values will be compromised. The supporters of surrogacy refer to it as 'giving life' or 'solving infertility', while the opponents consider it buying and selling babies. These ethical dilemmas combined with the varying laws and regulations governing surrogacy around the world make surrogacy an uncharted territory that is often difficult to navigate.

\section{Surrogacy Laws from an International Perspective}

Dividing the world into countries that allow surrogacy and countries that do not would be an easy way to analyze surrogacy from a legal perspective. However, the reality is much more complex: surrogacy laws vary greatly from one jurisdiction to another.

From a global perspective, it is impossible to find comparable moral or legal grounds between countries in this area. Because of this, creating common legal standards or moving forward with widespread international unification of substantive laws or rules regarding the recognition of the effects of foreign laws seems unrealistic. ${ }^{19}$

In most legal systems around the world, the principle of the mater semper certa est ${ }^{20}$ is still valid because maternity in the legal sense of the word is connected with the woman who gave birth to the child. However, in some legal systems, biology has been rejected as the foundation for family law. ${ }^{21}$

When examining surrogacy laws by country, we need to look at several key factors. First, are surrogacy contracts allowed, enforceable, prohibited, or void? Can a child become the subject of a contract? Does the country differentiate between traditional and gestational surrogacy? Does the jurisdiction differentiate between a commercial surrogacy contract and altruistic (or unpaid) surrogacy? Is there a formalized recognition process for the intended parents as legal parents (i.e., adoption post-birth)?

The first case to consider the validity of surrogacy contracts was the aforementioned Baby $\mathrm{M}$ case, in which the court held that such a contract was invalid. According to the New Jersey Supreme Court, the surrogacy contract by its very nature conflicts with laws prohibiting the use of money in adoption cases as well as laws requiring proof of parental

19 | Mostowik, 2019.

20 | The Code of Justinian (Corpus Iuris Civilis): "Mater semper certa est, etiamsi uolgo conceperit, pater uero is est, quem nuptiae demonstrant".

21 | Mostowik, 2019. 
unfitness before the termination of parental rights. ${ }^{22}$ The Baby $\mathrm{M}$ case still holds its status as a precedent. The New Jersey Supreme Court ruled that the Baby M judgment also applied to traditional and gestational surrogacy cases in the 2009 case of Robinson v. Hollingsworth (also known as A.G.R. v. D.R.H \& S.H.). ${ }^{23}$ The ruling was handed down by Judge Francis Schultz, who expanded the ruling in Baby $\mathrm{M}$ to recognize the gestational mother as the child's legal mother in a case involving a homosexual couple. The case involved an embryo created from an anonymous egg donor in vitro fertilized by one of the husbands' sperm. The sister of the other husband became the gestational mother and had no genetic link to the baby. Before the embryo was implanted, she signed a surrogacy contract with the understanding that upon childbirth, she would relinquish her legal rights to the child. The surrogacy resulted in a twin pregnancy. The surrogate mother carried the twins to full term and handed over the children to the couple. A year later, she asserted her parental rights despite her lack of genetic links to the children. Judge Schultz recognized her as the legal mother of the children by relying on the Baby M ruling. However, this ruling was somewhat controversial: some praised it for protecting the woman's right to the children she carried and birthed, stating that surrogacy contracts inherently exploit women. Many, however, criticized the ruling for being oblivious to the circumstantial differences of the Baby $\mathrm{M}$ case, in which the surrogate mother was the biological mother and this case, in which the surrogate mother was merely the vessel for carrying the children. This was especially important because over two decades had passed since the Baby M verdict, during which the practice of surrogacy had become more socially accepted.

Although surrogacy has transformed from a societal taboo to a widespread reproductive practice in many countries, many jurisdictions are hesitant to consider the validity of surrogacy contracts. It is clear, however, that as surrogacy becomes more widespread worldwide, the validity and enforceability of surrogacy agreements must be discussed. Classical contract law is not able to deal with the unequal power dynamics between the contracting parties, changing circumstances, or changes of heart. Modern contract law, however, should be able to provide a strong framework to regulate these issues.

Besides questions of validity and enforceability, we must also examine whether jurisdictions differentiate between commercial and altruistic surrogacy. Commercial surrogacy is a surrogacy practice in which the surrogate mother is monetarily reimbursed for her services. Altruistic surrogacy involves no monetary compensation for the surrogate for her services beyond reimbursement for medical costs and other reasonable expenses related to pregnancy. Most altruistic surrogacies occur among family members.

Article 3 (Right to the Integrity of the Person) of the Charter of Fundamental Rights of the European Union states that:

1. "Everyone has the right to respect for his or her physical and mental integrity.

2. In the fields of medicine and biology, the following must be respected:

a. Free and informed consent of the person concerned, according to the procedures laid down by law. 
b. the prohibition of eugenic practices, in particular those aiming at the selection of persons, the prohibition on making the human body and its parts as such a source of financial gain,

c. the prohibition of the reproductive cloning of human beings." ${ }^{24}$

Based on this, we can clearly conclude that commercial surrogacy is not an option in the European Union because monetary compensation for the time and energy of the surrogate would constitute 'financial gain' according to Article 3 . In addition to Article 3 , we can refer to Article 24, which protects the best interests of the child and provides guidance in this matter. Further, the European Parliament has discussed the question of surrogacy in recent years: in 2015, it condemned this reproductive practice, stating that surrogacy constitutes an offense against human dignity and purports the instrumentalization of the surrogate's body by treating her as an object of trade. Women in vulnerable situations are more likely to fall victim to exploitation through surrogacy. The European Parliament stated that it:

"Condemns the practice of surrogacy, which undermines the human dignity of the woman since her body and its reproductive functions are used as a commodity; considers that the practice of gestational surrogacy which involves reproductive exploitation and use of the human body for financial or other gains, in particular in the case of vulnerable women in developing countries, shall be prohibited and treated as a matter of urgency in human rights instruments." ${ }^{25}$

The same verbiage was used in annual reports, until the 2019 Annual Report presented a drastic change in this matter compared to the Parliament's approach in 2015-2018. Just a few years after the 2015 Annual Report explicitly condemned surrogacy, the European Parliament came to drastically different conclusions in January 2021, when voting on the Annual Report on Human Rights and Democracy in the World and the EU in 2019. One amendment touched on the topic of surrogacy and when asked to vote, 429 members of the European Parliament voted against condemning surrogacy on January 20, 2021, which is a clear majority. Eighty-seven Members of the European Parliament were undecided, and merely 142 members of the European Parliament concluded that the practice of surrogacy must be condemned. How did the same body arrive at such drastically different conclusions just a few years apart? One of the reasons for this change can be found in the Motion for a Resolution to the Annual Report for 2019-Human rights and democracy in the world and the EU policy on the matter. ${ }^{26}$ The drafted amendment was very controversial, and the language used was much harsher than that used in 2015. This may be the reason why so many members of the European Parliament disagreed with the amendment. The amendment stated that the European Parliament:

"Stresses the need to protect the dignity of every human being; condemns surrogacy as a universal crime that compromises the physical integrity of women and the rights of the child,

24 | European Union: Council of the European Union, Charter of Fundamental Rights of the European Union (2007/C 303/01), 14 December 2007, C 303/1, available at: https://www.refworld.org/ docid/50ed4f582.html [Accessed: 9 October 2021].

25 | European Parliament resolution of 17 December 2015 on the Annual Report on Human Rights And Democracy in the World 2014 and the European Union's policy on the matter (2015/2229(INI)). 26 | Human rights and democracy in the world and the EU policy on the matter - annual report 2019 (2020/2208(INI)). 
increasing the commercial exploitation of women's bodies and reducing the person to a commodity; rejects any improper use of the human body that involves reproductive exploitation for a mere economic or other type of return and calls for greater safeguards for the rights of women, especially for vulnerable women living in developing countries; believes that the practice of gestation for others should be addressed through international legislative instruments for the protection of human rights." ${ }^{27}$

After the vote was held among the Members of the European Parliament, the text of the amendment was not modified or rewritten; it was completely left out of the annual report for 2019. Thus, whereas in years prior, the stance of the European Parliament was a clear condemnation of commercial surrogacy practices, the general consensus is now silent. Practically, this means that the European Parliament went from extended protection from surrogacy to zero protection. This suggests that the European Union no longer has a unified approach to surrogacy, which could have serious human rights implications.

A similar approach was adopted by the Council of Europe, which ultimately condemned commercial surrogacy. The Committee on Social Affairs, Health, and Sustainable Development of the Parliamentary Assembly of the Council of Europe approved a draft recommendation related to surrogacy and the best interest of the child in 2016. ${ }^{28}$ The rapporteur of the draft recommendation was Professor Petra de Sutter, who aimed to raise sensitivity and awareness toward the exploitation of women and children. The draft recommendation stated that the Committee of Ministers should consider the feasibility of creating unified European guidelines to protect children's rights concerning surrogacy arrangements. The draft recommendation also suggested that the Committee of Ministers should collaborate closely with the Hague Conference on Private International Law regarding the status of children, including issues that might surface as a result of international surrogacy agreements. The Parliamentary Assembly of the Council of Europe voted to reject drafts 83 to 77 . This was not the first time that the Council refused to draw up surrogacy guidelines. The rapporteur stated that she thought the Committee was too divided on human rights questions related to surrogacy and that no agreement could exist between committee members on whether altruistic surrogacy should be admissible.

In the domain of the Court of Justice of the European Union, surrogacy issues are primarily related to the social rights of the commissioning parents. These social rights include questions of a practical nature-whether maternity or paternity leave should apply to the intended parents, whether a parental contribution should be awarded to the intended parents, and whether measures to safeguard the health of pregnant workers and workers who have recently given birth or are breastfeeding at the workplace should be applicable. Would the failure to grant these constitute discrimination? For this, one needs to refer to the judgment in Case C-363/12. ${ }^{29}$ Would it be a violation of the principle of

27 | Motion for a resolution Paragraph 27 a (new) - Human rights and democracy in the world and the EU policy on the matter - annual report 2019 (2020/2208(INI)).

28 | De Sutter, 2016.

29 | Court of Justice of the European Union, Judgment of the Court (Grand Chamber), 18 March 2014 (Request for a preliminary ruling from The Equality Tribunal - Ireland) - Z/A Government Department, the Board of Management of a Community School(Case C-363/12). 
equality? This was explored in Case C-167/12. ${ }^{30}$ Would it be a breach of Directive 2006/54/ $\mathrm{EC}^{31}$ of the European Parliament and of the Council of July 5, 2006, on the implementation of the principle of equal opportunities and equal treatment of men and women in matters of employment and occupation? ${ }^{32}$ The Court concludes in the judgments mentioned above that the social rights that are present in EU legislation are not directly applicable to the intended parents in the case of surrogacy. These rights should instead be regulated at the national level of the Member States, meaning that the Member States that do allow surrogacy should ensure that the rights of the intended parents are established correctly, and social rights become applicable to the intended parents in these Member States.

Thus, it is clear that there is no unified European approach to surrogacy, and the question remains regulated at the national level. Individual member states naturally have varying positions on surrogacy. Some member states prohibit the practice for moral reasons. They consider it a violation of human dignity, of both the surrogate mother and the child. Other member states, however, have a different stance on the topic and view surrogacy as part of the right to constitute a family, the freedom of disposition over one's own person, and bodily autonomy, among others. Global statistics show a constantly rising number of surrogacy cases, including a growing number of cross-border surrogacies. ${ }^{33}$ It bears mentioning that this trend was halted in 2020 by the global coronavirus pandemic, mainly due to travel restrictions, and this change of pace is anticipated to continue until the end of the pandemic. Many infertile European couples are now seeking a way to enter into a surrogacy agreement in their own jurisdiction, or if that is not an option, they often opt for reproductive tourism. It may thus be time to apply a unified approach to regulate this uncharted territory at the European level, as there is currently no unified legal instrument that addresses the issue of surrogacy. Some fragmentary regulations are provided by universal and regional international legal instruments, but the matter of surrogacy is still mostly regulated at the national level.

\section{| 3.1. National Surrogacy Legislation in Europe}

National legislation is incredibly diverse in this area. Among European countries, there are forbidding states, permitting states, and non-regulating states concerning the question of surrogacy. Further, some countries differentiate between traditional and gestational surrogacy and allow one, but not the other. Some countries also have citizenship requirements for commissioning parents and/or surrogates as an attempt to curb fertility tourism.

\subsubsection{States prohibiting surrogacy}

Most European countries prohibit surrogacy. France is one of the most notable examples here, banning all commercial and altruistic surrogacy agreements since the

30 | Court of Justice of the European Union, Judgment of the Court (Grand Chamber), 18 March 2014 (Request for a preliminary ruling from the Employment Tribunal, Newcastle upon Tyne - United Kingdom) - C. D./S. T. (Case C-167/12).

31 | Directive 2006/54/EC of the European Parliament and of the Council of 5 July 2006 on the implementation of the principle of equal opportunities and equal treatment of men and women in matters of employment and occupation.

32 | Karpat, 2018, pp. 91-106.

33 | Davletshina, Karmanov, 2020, p. 180. 
1990s. In 1991, the Court of Cassation held that only merchandise could be the object of contracts :

"The Court condemns maternity by substitution and related contracts, reaffirming in so doing the terms the court had used in a judgment of December 13, 1989 (Civ.1, Bull. no. 387) in approving the dissolution of an association whose objectives were to facilitate the signature and performance of contracts of that type. This judgment also clarifies that of 1991 in relation to the fact that such contracts impinge upon not only the unsaleable nature of the human body but also upon the status of persons, since, according to the judgment of 1989, they have as their objective 'to cause to come into the world a child whose status will not correspond with his real lineage." ${ }^{34}$

The Court further examined the question in 1994 and held that all contracts concerning procreation or gestation on behalf of a third party are null and void. This prohibition was codified in Article 16 of the French Civil Code. ${ }^{35}$ French legislation goes as far as making it a criminal offense to serve as an intermediary in a surrogacy procedure, punishable by imprisonment. The country is very clear about its stance on surrogacy; however, children of French citizens can still be born as a result of surrogacy tourism.

Italy is also on the list of forbidding states, banning both altruistic and commercial surrogacy on constitutional grounds. The Italian Constitution ${ }^{36}$ declares the irreplaceable duties and responsibilities of genetic progenitors toward their children, the right of children to be raised by their parents. This provision led Italy to enact a new law in 2004, the Act on Law on Assisted Reproductive Technologies n. 40 of 2004. Italy was one of the last countries that had no regulations on the assisted fertilization process. This was especially problematic because there had been over a hundred private clinics that were offering medically assisted reproductive procedures somewhere in a grey area of law. Law 40/2004 filled this legislative gap, although it did so in a restrictive manner. Surrogacy is further prohibited by the Italian Civil Code, which considers all surrogacy agreements null and void because they are against public policy. ${ }^{37}$

Germany is also in the forbidding state category. Germany considers surrogacy to be a violation of human dignity, which is enshrined in the first article of the German Constitution. ${ }^{38}$ The expansion of this concept led to the Act on the Protection of Embryos ${ }^{39}$ in 1991, which severely restricts reproductive medicine in Germany based on human dignity. This act criminalizes surrogacy techniques and anyone who has any role in the surrogacy process. The act also limits in vitro fertilization and only allows a woman to give birth to her own child. Thus, in vitro fertilization is only an option using the woman's own egg, which does not resolve the increasing issue of female infertility. Regarding surrogacy, the

34 | Case Procureur-général v. Cassation, D.1991.417.

35 | Code civil [Civil Code] art. 16 (Fr.).

36 | Costituzione della Repubblica Italiana, entrata in vigore il 1o gennaio 1948, era stata eletta il 2 giugno 1946. Italian Constitution (1947) Adopted on 22 December 1947 (published in Gazzetta Ufficiale, 27 December 1947, n.298).

37 | Italian Civil Code (1942) Adopted with Royal Decree n.262 (March 16, 1942) - Art. 1325.

38 | Basic Law for the Federal Republic of Germany (as amended July 2002) [Germany], 23 May 1949. 39 | Act 745/90, on the Protection of Embryos (Gesetzzum Schutz von Embryonen (Embryonenschutzgesetz - ESchG) - Federal Law Gazette, Part I, No. 69, issued in Bonn, 19th December 1990, p. 2746. 
German Civil Code (Bürgerliches Gesetzbuch) ${ }^{40}$ declares that the legal parents of the child will always be the gestating mother and her legal partner (or the man who recognizes his fatherhood), thus ruling out the ability of intended parents to become legal parents. Furthermore, the German Adoption Placement Act (Adoptionsvermittlungsgesetz) ${ }^{41}$ also excludes surrogacy cases from its procedures.

Further forbidding countries include Denmark, Sweden, Austria, and Poland.

\subsubsection{States allowing surrogacy}

Countries that allow surrogacy in Europe are exceptions to the regular normative framework. One of these countries is Portugal, which has traditionally been an opponent of surrogacy. Surrogacy contracts were banned in Portuguese legal order, and surrogacy has even been criminalized in Portugal. Act no. 32/2006 on medically assisted reproduction was enacted to regulate fertilization techniques and it expressly banned surrogacy contracts. Under this law, all surrogacy agreements were null and void. The law was heavily criticized because it recognized the gestational mother as the legal parent of the child, even if she had no genetic link to the baby and all genetic material came from the intended parents. This deprived the intended parents of their right to a family, and also imposed motherhood on the gestational mother even if she did not wish to parent the child. The prohibition was supported by a public order argument based on the Civil Code. Legal scholars have traditionally been more conservative in Portugal, and this was reflected in the legal position on surrogacy until 2016, when Act. N. 25/2016 was introduced to regulate surrogate motherhood. The 2016 law allows surrogacy in certain scenarios, that is, for women born without a uterus or with a serious disease of the uterus that would prevent them from carrying a child. ${ }^{42}$ Single men or gay couples were not able to become parties to a surrogacy contract, meaning that only heterosexual couples are allowed to become intended parents in a surrogacy procedure. This was later amended to allow any woman to enter a surrogacy contract regardless of her marital status or sexual orientation. Single gay men and male gay couples are still not permitted to use artificial reproductive technologies; men can only have access to reproductive technology if they are in a heterosexual relationship. This approach of the 2016 law is criticized by some as being discriminatory based on gender and sexual orientation. Another heavily criticized aspect of Portuguese surrogacy law is that it does not allow for changes of heart. There is no possibility of withdrawing from a surrogacy contract. While we can clearly observe the immense change in the Portuguese legislators' stance on surrogacy in the past fifteen years, commercial surrogacy is still fully prohibited and any monetary compensation for the services of the surrogate is criminalized. The only money that can be exchange is to cover the documented medical expenses related to the surrogate's pregnancy. To ensure that surrogacies were in line with legislation, the Medically Assisted Procreation National Council was established to supervise and review every surrogacy agreement. ${ }^{43}$

40 | Civil Code in the version promulgated on 2 January 2002 (Federal Law Gazette [Bundesgesetzblatt] I page 42, 2909; 2003 I page 738), last amended by Article 4 para. 5 of the Act of 1 October 2013 (Federal Law Gazette I page 3719).

41 | Adoption Placement Implementation Act of 5 November 2001 (German Federal Law Gazette I, p. 2950).

42 | Raposo, 2017, pp. 230-239.

43 | Ferreira and Almeida, 2020. 
Greece is also on the list of countries that allow surrogacy. Altruistic gestational surrogacy became legal in Greece, but traditional and commercial surrogacy is still fully prohibited. In 2002, Greece enacted Law 3089/2002, which modified Articles 1455 to 1464 of the Greek Civil Code. This was later expanded by Act 3305/2005 on the Enforcement of Medically Assisted Reproduction. The Greek Civil Code is very clear regarding the regulation of surrogacy. It states, that:

"The transfer of a fertilized ova into the body of another woman (the ova should not be hers) and the pregnancy by her is allowed by a court authorization granted before the transfer, given that there is a written and, without any financial benefit, agreement between the persons wishing to have a child and the surrogate mother and in case that the latter is married of her spouse, as well. The court authorization is issued after an application of the woman who wants to have a child, provided that evidence is adduced not only in regard to the fact that she is medically unable to carry the pregnancy to term but also to the fact that the surrogate mother is in good health and is able to conceive." 44

Three years after the amendment of the Greek Civil Code, Act 3305/2005 on the Enforcement of Medically Assisted Reproduction was enacted. This contains further regulations regarding the conditions of legal surrogacy. It bans traditional surrogacy, explicitly stating that the surrogate mother cannot contribute her own genetic material, prohibiting commercial surrogacy, and explicitly states that the only monetary compensation that can occur is for the medical expenses related to the pregnancy and the loss of profit. It also limits the valid reasons for surrogacy to medical issues faced by the intended mother, including infertility or the potential of genetic hereditary diseases. As in Portugal, the intended parents can only be single women or heterosexual couples. The surrogate has to undergo an extensive medical check, be healthy, and be under the age of 50. All involved parties must be Greek citizens or permanent residents of Greece. To ensure that all of these legal requirements are met, all surrogacy agreements are subject to judicial review. This process is not without its critics, especially because this type of judicial control is very vague and, in most cases, reduced to a mere bureaucratic procedure. The surrogacy process can only start after a judicial decision is issued by the district court in the commissioning parents' district of residence. The intended mother must apply to the court and fertilization can only happen after the judicial decision has been published. The biggest problem with the Greek system is that even though it is legally forbidden, commercial surrogacy is thriving. In many cases, judges agree to surrogacy even when there is no prior relationship between the commissioning parents and the surrogate..$^{45} \mathrm{Judgments}$ in these cases are more akin to administrative decisions and often purely formal. This is also evident from the number of private clinics in Greece advertising commercial surrogacy. ${ }^{46}$

Other countries that allow surrogacy in the European Union include Cyprus, Belgium, and the Netherlands. It is important to note that while Ukraine is not a European Union member state, it is an example of a country with very liberal surrogacy laws. The Ukrainian Family Code permits all forms of surrogacy in Article 123 but balances that with somewhat more restrictive requirements for the intended parents (heterosexual couples or single adults with medical conditions) and the surrogate (a woman who has already

44 | Article 1458 of the Greek Civil Code.

45 | Hatzis, 2010.

46 | Davaki, 2017, p. 8. 
given birth to her own child). All surrogacy contracts are made in front of a notary, with a notable difference compared to permissive European Union member states: monetary compensation is allowed with no cap limit. Ukraine also recognizes the right to regret, that is, the surrogate mother's right to change her mind and withdraw from the contract before the transfer. These relatively liberal regulations make Ukraine one of the most popular destinations for reproductive tourism. The main issue surrounding surrogacy maternity in Ukraine is the lack of a clear mechanism of action when citizens of countries where such procedures are prohibited plan to participate in the program. ${ }^{47}$

\subsubsection{States not fully regulating surrogacy}

As of 2021, some European countries still have no restrictive or permissive surrogacy laws. However, this does not make them exempt from dealing with the legal consequences of surrogacy in some way.

In some countries, a lack of regulation means implied permission. This is the case in Romania, for example, where there are no laws governing surrogacy, making it technically legal even though no laws regulate or explicitly allow it. In Romania, commissioning parents could reach an agreement with the surrogate, sign the contract in front of a notary, and, after birth, complete the process through adoption. There is a historical reason for this significant legislative gap: during the era of state socialism, abortions were prohibited, which resulted in the death of over ten thousand women due to illegal abortions. Thousands of women were imprisoned. After the fall of socialism and decades of state invasion in the private lives of citizens, the legislators of the new era were reluctant to intervene in issues related to assisted reproduction. Several attempts have been made to introduce a comprehensive legal framework, none of which have been successful. The current state of things is fragmented, with only partial provisions in the Healthcare Act and the Civil Code, which could be somewhat applicable to the question of surrogacy.

The question of surrogacy was also discussed by Romanian courts, including the Romanian Constitutional Court, which debated questions related to surrogacy when a draft law was presented in the Romanian Parliament on assisted reproduction. ${ }^{48}$ The President of Romania challenged the draft law and the Constitutional Court had to examine its alignment with the Constitution and human rights standards. This draft required that the intended parents and surrogate become parties to an agreement, according to which the surrogate needed her husband's permission to carry a baby. This would have violated the surrogate's freedom of disposition over her own person and bodily integrity. ${ }^{49}$ The Court deemed the draft law unconstitutional and stated that "the life and health of a person and of the conceived child, but not yet born, cannot be objects to transactions." ${ }^{50}$ It is important to note, however, that surrogacy still exists in Romania due to the grey areas of Romanian law, and courts are frequently confronted with the children's filiation with genetic vs. gestational parents.

47 | Mostowik, 2019.

48 | Brodeala, 2016, pp. 56-74.

49 | Article 26(2) of the Romanian Constitution.

50 | Decision 418 of 18 June 2005 on the complaint of unconstitutionality of the law on reproductive health and medically assisted human reproduction, published in Official Gazette no 664 of 26 July 2005, 3 b) (Constitutional Court of Romania 2005). 
Unlike Romania, some countries with a legislative gap regarding surrogacy deal with the issue with an implicit prohibition of the practice. An example of this is Poland, a country that has no explicit ban on surrogacy. We can arrive at an implicit ban by analyzing the Family and Guardianship Code of Poland, which states that the legal mother of a child is the woman who gave birth to the child..$^{51}$ This provision was added to the Family and Guardianship Code in 2009, and in the explanation of the draft law, the specific definition of the term 'mother' was necessary in light of ever-evolving medical technologies. They backed up their definition by arguing that it is in line with the European Convention on the Legal Status of Children Born out of Wedlock. Article 2 of the Convention states that: "Maternal affiliation of every child born out of wedlock shall be based solely on the fact of the birth of the child." ${ }^{52}$ According to Polish legal scholars, ${ }^{53}$ this means that any surrogacy agreements are null and void, and the surrogate mother will always be considered the legal parent of the child, even if she has no genetic ties to the child.

The highest-level source of law in Hungary is the Fundamental Law of Hungary, which protects the institution of marriage as a union between a man and a woman and encourages them to commit to having children. Surrogacy agreements are not recognized or enforceable in Hungary, and the Health Act implicitly bans them by excluding surrogacy from the list of reproductive procedures that can be legally performed. The Hungarian Criminal Code also prohibits commerce with the human body, but surrogacy itself is not a criminal offense, even though opinions differ regarding its legality. However, some loopholes are present: surrogacy procedures cannot be conducted legally in Hungary, but children born through altruistic surrogacy abroad can be adopted. To get around this, many couples travel with their surrogates to a country in which human reproductive procedures can be legally performed.

In the Czech Republic, there is a prohibition on commercial surrogacy based on the general principle that the use of human body parts may not be a source of financial gain or other benefits for the person from whose body the parts are to be taken, or for anyone else, including the medical institution that performed the procedure. "The human body cannot be sold, donated, exchanged, borrowed, or rented. Nothing of this kind is permitted by law. The human body can be classified in the category of so-called material objects, which, however, cannot be qualified as a thing (...); it is, therefore, res extra commercium, which does not have the nature of a thing." 54 The first case of surrogacy was recorded in the Czech Republic in 1993 at the Clinic of Reproductive Medicine and Gynecology in Zlín, involving an adoptive mother whose uterus had been surgically removed and who was, therefore, unable to carry a child to term. The entire course of this action was conducted in secret until 2004. At the above-mentioned clinic, however, surrogacy was not only openly discussed but also offered to those interested in this type of reproduction. However, legislation is still lagging behind, and surrogacy is not expressly forbidden or expressly allowed. For a long time, the legislator simply pretended that there was no such thing as surrogate motherhood. This changed in 2012 with the new Civil Code, which was considered a major letdown due to its lack of an in-depth consideration of the matter of

$51 \mid$ Art. $61^{9}$ of the Family and Guardianship Code.

52 | European Convention on the Legal Status of Children born out of Wedlock CETS No. 085, adopted on 15 November 1975.

53 | Jędrejek, 2014, p. 102.

54 | Tesinova, Ždarek, Policar, 2011, p. 185. 
surrogacy. It does, however, at least mention surrogacy once, ${ }^{55}$ which is a sign that the legislator has acknowledged the existence of surrogacy. Czech law defines the mother as a woman who gave birth to her child. ${ }^{56}$ Determining fatherhood is more complex, and fatherhood is linked to the genetic connection to the child. The regulation of surrogacy in the Czech Republic currently lacks a more precise legislative framework.

In Slovakia, the first legal analysis of surrogate motherhood was published over 35 years ago. ${ }^{57}$ After the 2004 reveal of the Czech clinic conducting surrogacy procedures since the 1990s, a renewed interest in surrogacy emerged in Slovakia as well. Like our partnering countries in V4, Slovakia is just as lacking when it comes to a comprehensive regulatory framework on surrogacy issues. Article 82 (2) of the Family Act is the only provision that can be applied to surrogacy. ${ }^{58}$ This provision makes all surrogacy contracts null and void. Article 82 of the Family Act states the following:

(1) The mother of the child was a woman who gave birth to the child.

(2) Agreements and contracts that are contrary to paragraph (1) shall be null and void.

The explanatory report for this provision refers to the state of medical science and its rapid progress. As with many other European states, it became necessary to define the term 'mother' for the sake of clarity and to reduce maternity establishment disputes. It is worth mentioning, however, that with in vitro fertilization, the woman who gives birth to a child (gestational mother) is not necessarily the biological or genetic mother of the child, and has no common DNA with the child. This is a fact that most jurisdictions seem to overlook and focus solely on the circumstances of the birth of the child to determine maternity. Section 2 of Article 82 of the Family Act explicitly warns that any agreements contrary to Section 1 are void. This seems to be a direct response to surrogacy and thus voids all surrogacy contracts. In addition to family act reasoning, we can also conclude that surrogacy contracts are contra bonos mores in our legal environment; therefore, they would not have any legal protection in Slovak jurisdiction. ${ }^{59}$

\section{Conclusion}

We can conclude that there is immense jurisdictional diversity across Europe when it comes to matters related to surrogacy. To prevent legal obscurity and grey areas that could ultimately result in the failure of the mutual trust principle, it is not sufficient to deal with surrogacy at the national level. Surrogacy is a cross-border issue that requires a cross-border solution; therefore, it is time to take action at a European level. The need for a unified legal framework addressing international surrogacy cases has been the focus of the Hague Conference on Private International Law for the past 20 years. The Hague Conference is currently researching private international law issues related to the legal parentage of children, as well as international surrogacy contracts. The work was set to conclude with a protocol by 2023.

55 | Art. 804 of Act no. 89/2012 Coll., Civil Code.

56 | Art. 775 of Act no. 89/2012 Coll., Civil Code.

57 | Haderka, 1986, pp. 917-934.

58 | Act No. 36/2005 on Family and on amendment of some other acts.

59 | Júdová, Píry, 2019, p. 794. 
Some experts in the field suggest that due to the progressively growing differences between domestic laws and legal principles (such as the concepts of maternity, paternity, the interpretation of prohibition of human trafficking and exploitation) and because of the lack of competence of international bodies in this field, no universal approach will be possible in the future, but rather co-operations within different states representing similar values are likely to occur. ${ }^{60}$ This is why tighter collaboration and legal research on the identities of national legal systems are crucial when discussing the future of surrogacy in law-one of the reasons organizations like the Central European Professors' Network provide invaluable insight into these domestic laws and principles and contribute to solving many issues related to surrogacy.

If we want to pursue a unified European framework, we have two options. First, the abolitionist path-this would mean banning surrogacy across the continent on the grounds that surrogacy violates human dignity. This being a fundamental right deserves protection and thwarts the human body from becoming an article of commerce. The complete abolition of surrogacy could lead to further legal issues, especially in countries that have historically allowed surrogacy procedures. Moreover, we can assume that the ban on surrogacies would not necessarily lead to the eradication of the practice in Europe; it would most likely continue in secret and lead to legal evasion and the potential exploitation of women in vulnerable positions.

The second option is the regulatory path. This would require legislators to catch up with societal changes and accept that surrogacy exists, even in countries that explicitly or implicitly prohibit it. By acknowledging the reality of surrogate motherhood and harmonizing the various national jurisdictions of Europe, we could achieve a minimum level of protection for the fundamental rights involved.

Irrespective of which path we choose for the future regulation of surrogacy, it is crucial that legislators shape legal instruments regarding surrogacy in compatibility with human dignity, fundamental moral principles, the best interest of the child, and the protection of families and humanity at large. 


\section{Bibliography}

Behm, L. (1999) 'Legal, Moral \& International Perspectives on Surrogate Motherhood: The Call for a Uniform Regulatory Scheme in the United States', DePaul Journal of Health Care Law, 2(3), pp. 557-603.

Brodeala, E. (2016) 'The Legal Status of Assisted Human Reproduction in Romania. A Brief Discussion on Surrogacy', Romanian Journal of Comparative Law, 2016/1, pp. 56-74.

Davaki, K. (2017) 'Surrogacy arrangements in austerity Greece: policy considerations in a permissive regime' in Davies, M. (ed.) Babies for Sale? Transnational Surrogacy, Human Rights and the Politics of Reproduction. London: Zed Books; https://doi. org/10.5040/9781350218567.ch-008

Davletshina, L., Karmanov, M. (2020) 'Surrogate Motherhood as an Object of Statistical Research', Vestnik Universiteta, 2020/7, pp. 176-183; https://doi. org/10.26425/1816-4277-2020-7-176-183

De Sutter, P. (2016) Children's rights related to surrogacy [Online]. Available at: http://assembly.coe.int/nw/xml/XRef/Xref-DocDetails-EN.asp?fileid=230158lang=2 [Accessed: 31 August 2021].

Dunson, D., Baird, D., Colombo, B. (2004) 'Increased Infertility with Age in Men and Women', Obstetrics and Gynecology, 103(1), pp. 51-56; https://doi.org/10.1097/01. AOG.0000100153.24061.45

Erdősová, A. (2014) 'Náhradné materstvo právne a eticky, alebo nakol'ko platí: mater semper certa est, pater incertus', Justičná revue, 66(12),

Erdősová, A. (2016) Aktuálne otázky o človeku a jeho právach v bioetike. Bratislava: Wolters Kluwer.

Ferreira, N., Almeida, S. (2020) Portuguese report on immoral contracts. Cambridge: Intersentia [Online]. Available at: https://ideas.repec.org/p/osf/socarx/hs3nb.html (Accessed:10 January 2022); https://doi.org/10.31219/osf.io/hs3nb

| Haderka, J. (1986) ‘Surogační mateřství’, Právny obzor, 69(10), pp. 924 ff.

Hatzis, A. (2010) The Regulation of Surrogate Motherhood in Greece [Online]. Available at: https://papers.ssrn.com/sol3/papers.cfm?abstract_id=1689774 (Accessed: 10 January 2022); https://doi.org/10.2139/ssrn.1689774

| Jędrejek G. (2014) Kodeks rodzinny i opiekuńczy. Warszawa: Wolters Kluwer.

Júdová, E., Píry, M. (2019) 'Surrogacy motherhood in the Slovak Republic - an illegal immigrant?' in Mostowik, P. (ed.) Fundamental legal problems of surrogate motherhood: Global perspective. Warszawa: Wydawnictwo Instytutu Wymiaru Sprawiedliwości.

Karpat, A. (2018) ‘Zákaz diskriminácie pracovníkov v judikatúre Súdneho dvora EÚ’ in Volný pohyb osôb a vnútorný trh Európskej únie. Bratislava: Euroiuris. 
Lasker, S.P. (2016). 'Surrogacy' in ten Have, H. (ed.) Encyclopedia of Global Bioethics. Springer; https://doi.org/10.1007/978-3-319-05544-2_409-1

Maganto Pavón, E. (2003) 'Enrique IV de Castilla (1454-1474). Un singular enfermo urológico. Una endocrinopatía causa de los problemas uro-andrológicos del monarca. Infertilidad o esterilidad. Intentos de inseminación artificial (IV)', Archivos Españoles de Urología, 56(3), pp. 233-241.

Mostowik, P. (2017) 'Legislative activities of European Union versus fundamental principles of paternity and maternity in Member States', International Journal of the Jurisprudence of the Family, Vol. 8, pp. 79-94 [Online]. Available at: https://ssrn.com/ abstract $=3224049$.

Mostowik, P. (2019) Fundamental legal problems of surrogate motherhood: Global perspective. Warsaw: Wydawnictwo Instytutu Wymiaru Sprawiedliwości.

Ombelet, W., Robays, J. (2015) 'Artificial insemination history: hurdles and milestones', Facts Views Vis Obgyn, 7(2), pp. 137-143.

Patel, N., Jadeja, Y., (2018) 'Insight into Different Aspects of Surrogacy Practices', Journal of Human Reproductive Sciences, 11(3), pp. 212-218; https:/doi.org/ 10.4103/ jhrs.JHRS_138_17

Posner, R. (1989) 'The Ethics and Economics of Enforcing Contracts of Surrogate Motherhood', Journal of Contemporary Health Law and Policy, 5(1), pp. 21-31 [Online]. Available at: https://scholarship.law.edu/jchlp/vol5/iss1/5

Raposo V. L. (2017) 'The new Portuguese law on surrogacy - The story of how a promising law does not really regulate surrogacy arrangements', JBRA Assisted Reproduction, 21(3), pp. 230-239; https://doi.org/10.5935/1518-0557.20170044

Sartin, J. (2004) 'J. Marion Sims, the Father of Gynecology: Hero or Villain?' Southern Medical Journal, 97(5), 500-505; https://doi.org/10.1097/00007611

Skidmore, M., Anderson, G., Eiswerth, M. (2012) 'The Child Adoption Marketplace', Public Finance Review, 44(2), pp. 163-196; https://doi.org/10.1177/1091142114547412

Solinger, R. (2000) Wake Up Little Susie: Single Pregnancy and Race Before Roe v. Wade. Oxfordshire: Routledge; https://doi.org/10.4324/9780203950685

Steptoe, P.C., Edwards, R. G. (1978) 'Birth after the reimplantation of a human embryo', Lancet, 312(8085); https://doi.org/10.1016/s0140-6736(78)92957-4

| Tesinova, J., Ždarek, R., Policar, R. (2011) Medicínske právo. Praha: C. H. Beck. 